\title{
Variation of Vitamin B12 level in Full Term Neonates with Jaundice Treated by Phototherapy
}

\author{
H.A.El Ghayati ${ }^{1}$, Y.M.Ismael ${ }^{2}$, E.H.Assar ${ }^{1}$ and S.E.Salem $^{1}$ \\ ${ }^{1}$ Pediatrics Dept., Faculty of Medicine, Benha Univ., Benha, Egypt \\ ${ }^{2}$ Clinical Pathology Dept., Faculty of Medicine, Benha Univ., Benha, Egypt \\ E-Mail:drmoha2030@gmail.com
}

\begin{abstract}
Neonatal jaundice alludes to the yellow hue of the skin and sclera of infants that outcomes from the testimony of bilirubin. VitB12 is critical for development and multiplication of red platelets (RBCs). Lack of The point of this examination was to assess variety in nutrient B12 level in embittered full term youngsters treated by phototherapy. Strategies: This examination was a case control study, which was done on 100 full term infants partitioned as cases gathering: fifty babies with jaundice treated by phototherapy, were tried out the investigation as an examination gathering. Control gathering: fifty ordinary full term youngsters. This investigation was led on infants who were conceded in the neonatal emergency unit Benha Children Hospital and Benha University Hospital) in the age gathering of 3-7 days. Full history, complete clinical assessment and research facility examinations included: serum VitB12 level before phototherapy and 24 hour after phototherapy were estimated. Results: Patient gathering was essentially connected with higher TSB when contrasted with control gathering, there were measurably huge lessening in Serum VitB12 level among cases bunch than control gathering. There was measurably critical negative connection between's serum VitB12 level and (complete serum bilirubin levels (TSB) and DSB. Serum VitB12 level was expanded after phototherapy. End: Full term children with backhanded hyperbilirubinemia had lower serum levels of nutrient B12 than sound full term youngsters. Phototherapy could build the degree of serum nutrient B12 in youngsters with roundabout hyperbilirubinemia.
\end{abstract}

Keywords: Vitamin B12- Jaundice- Phototherapy.

\section{Introduction}

Hyperbilirubinemia is one of the commonest reasons for admission to clinic in the neonatal period among term babies in all settings [1].

Neonatal jaundice is related with expanded unconjugated bilirubin focuses brought about by the breakdown of red platelets. Bilirubin can harm neurologic tissue and lead to bilirubin-actuated neurologic brokenness. Bilirubin in itself isn't totally adverse and can apply a physiological defensive impact because of its cancer prevention agent properties [2].

Jaundice is the most well-known purpose behind confirmation during the first month of life. Numerous factors (maternal, juvenile, during work and natural elements) influence the course and seriousness of jaundice. In spite of the fact that there might be an advantage to patients with gentle hyperbilirubinemia, the subjects with high height of serum bilirubin are jeopardized because of aggregation of bilirubin in the cerebrum tissue [3].

Nutrient B12 (Cobalamin) is a water-solvent nutrient that is gotten from creature items meat, dairy, and eggs. Inherent factor is a glycoprotein that is created by parietal cells in the stomach and vital for the retention of $\mathrm{B} 12$ in the terminal ileum, for example, red. When assimilated, B12 is utilized as a cofactor for catalysts that are engaged with the combination of DNA, unsaturated fats, and myelin. Therefore, a B12 lack can prompt hematologic and neurologic side effects. B12 is put away in abundance in the liver; nonetheless, in cases in which B12 can't be retained for a drawn out period (e.g., dietary inadequacy, malabsorption, absence of characteristic factor), hepatic stores are exhausted, and lack happens [4].

The significance of folate and nutrient B12 for solid neurological turn of events and capacity is unchallenged. Folate and nutrient B12 are needed for natural methylation and DNA blend. Nutrient B12 likewise partakes in the mitochondrial catabolism of odd-chain unsaturated fats and some amino acids. Characteristic mistakes of their digestion and extreme healthful inadequacies cause genuine neurological and hematological pathology. Helpless folate and nutrient B12 status is related with expanded danger of psychological disability, gloom, Alzheimer's illness and stroke among more established grown-ups and expanded danger of neural cylinder absconds among kids destined to moms with low [5].

This examination meant to assess of variety in nutrient B12 level in embittered full term children treated by phototherapy.

\section{Patients and Methods \\ 2.1 Patients}

This study was a case control study, which was done on 100 full term newborn babies divided as cases group: fifty newborns with jaundice treated by phototherapy, were enrolled in the study as a study group. Control group: fifty normal full term neonates. This study was conducted on newborn babies who were admitted in the neonatal intensive care unit at Benha Childern Hospital and Benha University Hospital) in the age group of 3-7 days. This study was conducted during the period from March 2020 to September 2020 


\section{Study group}

Fifty newborns with jaundice treated by phototherapy, were enrolled in the study as a study group.

\section{Control group}

Fifty normal full term neonates.

\section{Inclusion criteria}

- Full term

- Weight > $2500 \mathrm{gm}$

- Age 3-7days

- Jaundice required phototherapy for more than 24 hours, according to NICE guidelines (2018) for treatment of neonatal jaundice

- Indirect hyperbilirubinemia

\section{Exclusion criteria}

- Preterm babies

- Weight $<2500 \mathrm{gm}$

- Patients with sepsis

- Patients with RDS

- Patients required IV fluids

- Patients receiving IVIG

\section{Site of the study}

Benha University hospitals and Banha children hospital.

\subsection{Methods}

All studied cases were subjected to the following:

1. Detailed history taking:

- Personal history of mother: Age, residence and socio-economic Status.

- Natal history; mode of delivery

\section{Investigations}

All patients were subjected to:

- Complete blood count, Retics: CBC was done for all samples using sysmex KX-21N (Sysmex Corporation, New York, USA) for red blood cell (RBC) count, hemoglobin level, hematocrit value, WBC count (total and differential), and platelet count.

- Serum bilirubin total and direct. Assessment of levels of Total and direct bilirubin are competed automatically using a Dialab autolayzer.

- Serum VitB12 level before phototherapy and 24 hours after phototherapy. Architect i2000 (Abbott Diagnostics, USA) using the chemiluminescence micro particle immunoassay (CMIA) method for serum vitamin B12.

\subsection{Ethical consideration}

- An informed consent was obtained from parents before enrollment in the study.

- An approval from Research Ethics Committee in Benha Faculty of Medicine were obtained.

\subsection{Statistical analysis}

The gathered information were arranged and broke down utilizing SPSS adaptation 24 programming (Spss Inc, Chicago, ILL Company). Clear cut information were introduced as number and rates. Chi square test (X2), or Fisher's definite test (FET) were utilized to investigate absolute factors. Quantitative information were tried for ordinariness utilizing Kolomogrov Smirnove test accepting ordinariness at $\mathrm{P}>0.05$. Quantitative information were communicated as mean \pm standard deviation, middle and reach. Understudy " $t$ " test was utilized to examine typically circulated factors among 2 autonomous gatherings, or Man Whitney $U$ test for nonparametric ones. Understudy's combined t-test was utilized to evaluate the measurable centrality of the distinction between two populace implies in an investigation including matched examples. Spearman's connection coefficient (rho) was utilized to evaluate relationship between's non parametric factors.

$P$ value was considered significant as the following:

- $\mathrm{P}>0.05$ : Non significant

$\bullet \mathrm{P} \leq 0.05$ : Significant

\section{Results}

- There was no statistically significant difference between Cases group and control group regarding age, sex and mode of delivery Table (1).

- There was statistically significant increase in TSB and DSB among cases group than control group Table (2) Fig (1).

- There was statistically significant decrease in Serum VitB12 level among cases group than control group Table (3) Fig (2).

- This table shows there were no statistically significant positive correlation between Serum VitB12 level and (gestational age, SBP, DBP, HR and wt), and there were no statistically significant negative correlation between Serum VitB12 level and RR, while there were statistically significant negative correlation between Serum VitB12 level and (TEMP, Retics, TSB, DSB, TLC, hct and hb), and there was statistically significant positive correlation between Serum VitB12 level and (age, plat) Table (4).

- Serum VitB12 level was increased after phototherapy Table (5). 
Table (1) Comparison between cases group and control group regarding demographic data.

\begin{tabular}{|c|c|c|c|c|c|c|}
\hline & & & $\begin{array}{c}\text { Cases group } \\
(\text { No. }=50)\end{array}$ & $\begin{array}{c}\text { control group } \\
(\text { No. }=50)\end{array}$ & t.test & P. value \\
\hline Age (Day) & \multicolumn{2}{|c|}{ Mean \pm SD } & $4.30 \pm 0.52$ & $4.10 \pm 0.76$ & -2.423 & 0.07 \\
\hline \multirow[t]{2}{*}{ Sex } & Female & $\begin{array}{c}\text { No. } \\
\%\end{array}$ & $\begin{array}{c}20 \\
40.0 \%\end{array}$ & $\begin{array}{c}22 \\
44.0 \%\end{array}$ & $\begin{array}{c}\mathrm{X} 2 \\
0.164\end{array}$ & 0.685 \\
\hline & Male & $\begin{array}{l}\text { No. } \\
\%\end{array}$ & $\begin{array}{c}30 \\
60.0 \%\end{array}$ & $\begin{array}{c}28 \\
56.0 \%\end{array}$ & & \\
\hline $\begin{array}{l}\text { Mode of } \\
\text { delivery }\end{array}$ & $\begin{array}{c}\text { Caesarian } \\
\text { section } \\
\text { Normal } \\
\text { vaginal } \\
\text { delivery }\end{array}$ & $\begin{array}{c}\text { No. } \\
\% \\
\text { No. } \\
\%\end{array}$ & $\begin{array}{c}32 \\
64.0 \% \\
18 \\
36.0 \%\end{array}$ & $\begin{array}{c}31 \\
62.0 \% \\
19 \\
38.0 \%\end{array}$ & $\begin{array}{c}\mathrm{X} 2 \\
0.04\end{array}$ & 0.835 \\
\hline
\end{tabular}

Table (2) Comparison between cases group and control group regarding TSB and DSB.

\begin{tabular}{lccccc}
\hline & & $\begin{array}{c}\text { Cases group } \\
(\text { No. }=50)\end{array}$ & $\begin{array}{c}\text { control group } \\
\text { No. }=\mathbf{5 0})(\end{array}$ & t.test & P. value \\
\hline TSB & Mean \pm SD & $18.89 \pm 3.66$ & $2.48 \pm 0.77$ & 31.083 & 0.000 \\
DSB & Mean \pm SD & $1.09 \pm 0.41$ & $0.32 \pm 0.24$ & 11.491 & 0.000 \\
\hline
\end{tabular}

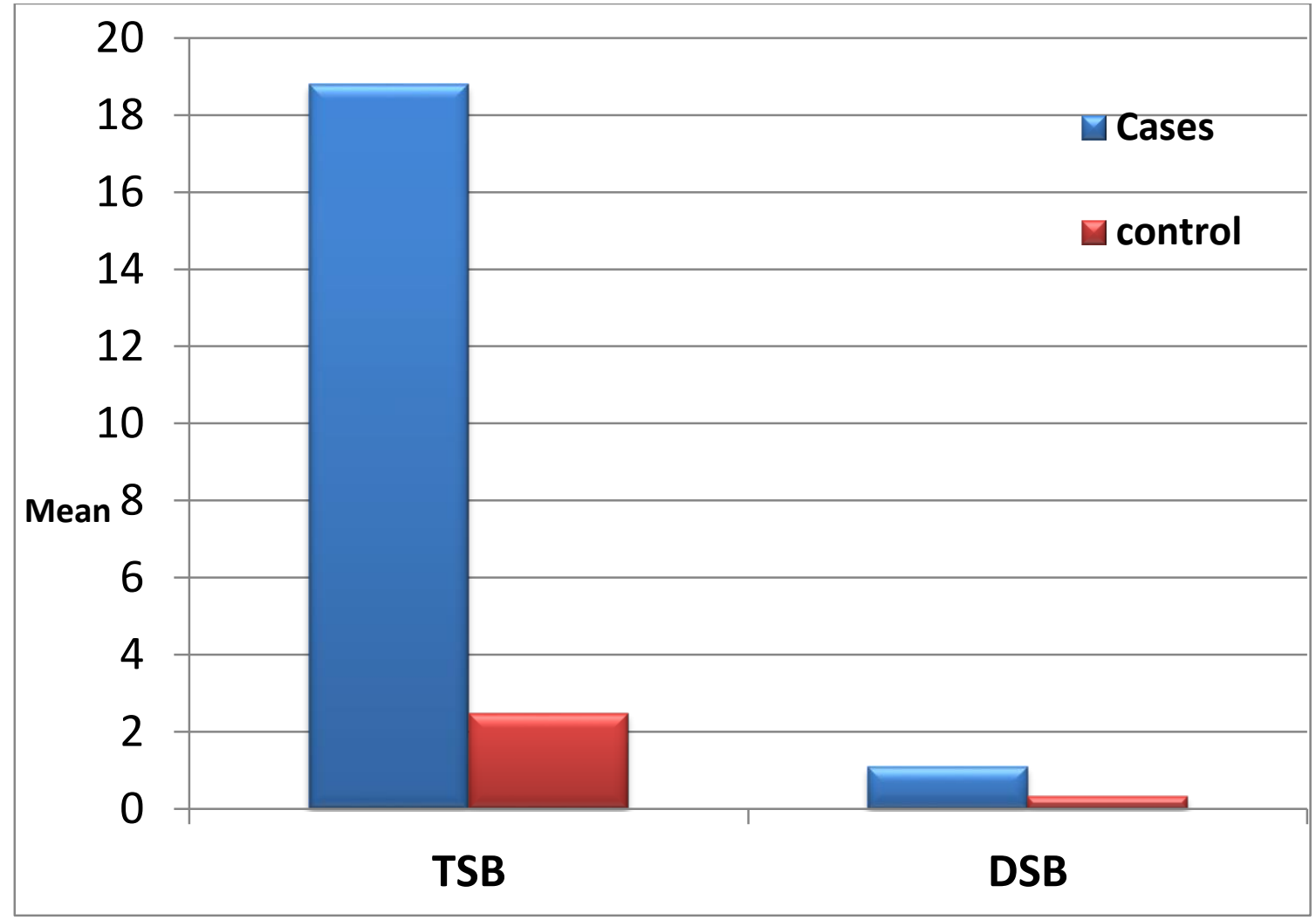

Fig (1) Comparison between cases group and control group regarding TSB and DSB.

Table (3) Comparison between cases group and control group regarding Serum VitB12 level.

\begin{tabular}{lccccc}
\hline & & $\begin{array}{c}\text { Cases group } \\
(\text { No.= 50) }\end{array}$ & $\begin{array}{c}\text { control group } \\
(\text { No.= 50) }\end{array}$ & t.test & P. value \\
\hline Serum VitB12 level & Mean \pm SD & $211.50 \pm 26.02$ & $417.48 \pm 60.91$ & -21.992 & 0.000 \\
\hline
\end{tabular}




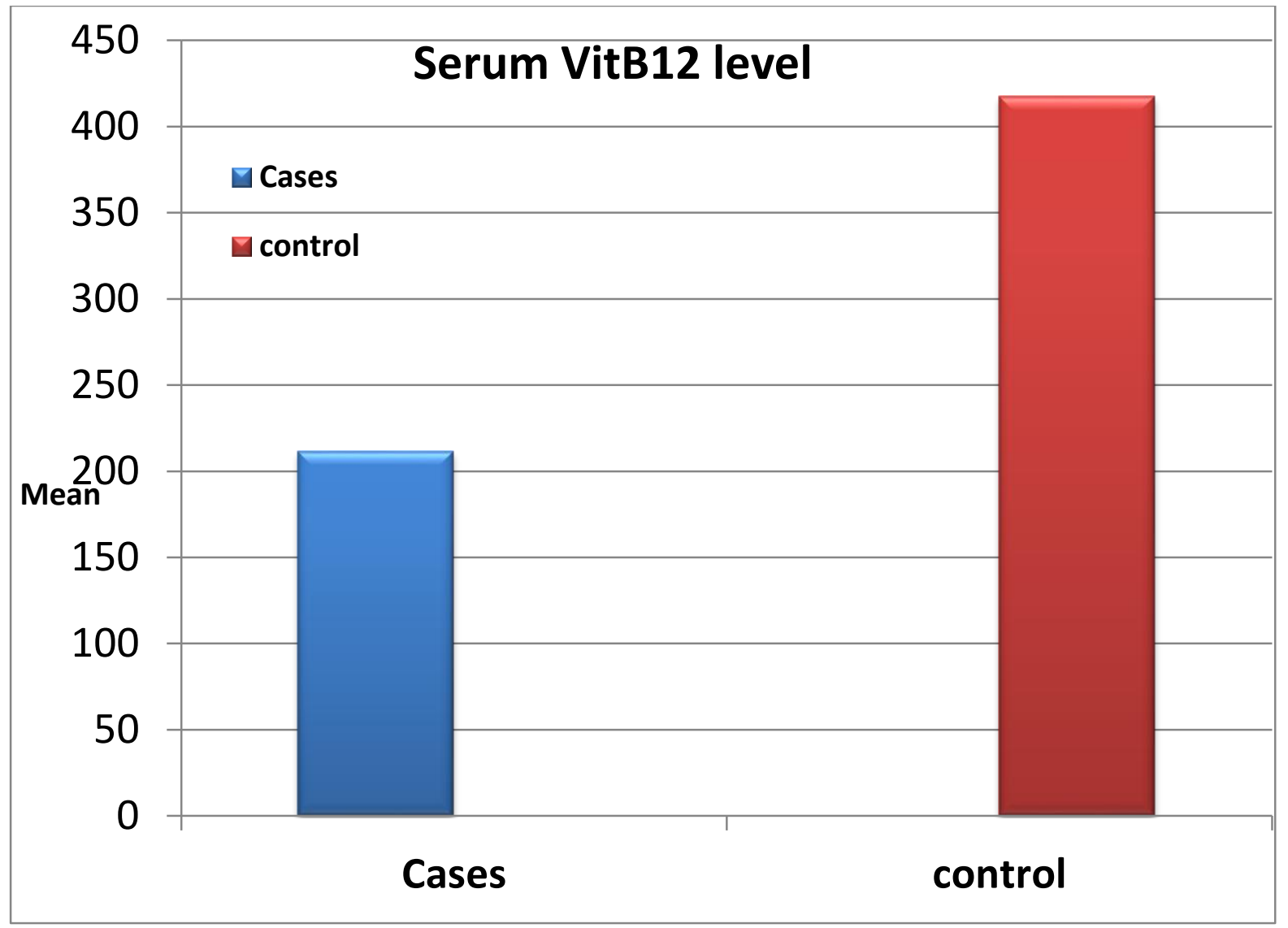

Fig (2) Comparison between cases group and control group regarding Serum VitB12 level.

Table (4) Correlation between Serum VitB12 level and other variables.

\begin{tabular}{|c|c|c|}
\hline \multirow[t]{2}{*}{ Correlation } & \multicolumn{2}{|c|}{ Pearson's correlation } \\
\hline & $\mathbf{r}$ & $\mathbf{p}$ \\
\hline Age (Day) * Serum VitB12 level & .191 & 0.05 \\
\hline $\begin{array}{l}\text { Gest age (wks) * Serum VitB12 } \\
\text { level }\end{array}$ & .052 & 0.606 \\
\hline SBP * Serum VitB12 level & .070 & 0.491 \\
\hline DBP * Serum VitB12 level & .059 & 0.562 \\
\hline TEMP $*$ Serum VitB12 level & $-.277-$ & 0.005 \\
\hline RR * Serum VitB12 level & $-.063-$ & 0.530 \\
\hline HR * Serum VitB12 level & .081 & 0.425 \\
\hline wt $*$ Serum VitB12 level & .154 & 0.127 \\
\hline Retics * Serum VitB12 level & $-.387-$ & 0.000 \\
\hline TSB $*$ Serum VitB12 level & $-.883-$ & 0.000 \\
\hline DSB * Serum VitB12 level & $-.708-$ & 0.000 \\
\hline plat $*$ Serum VitB12 level & .222 & 0.027 \\
\hline tlc $*$ Serum VitB12 level & $-.213-$ & 0.033 \\
\hline hct $*$ Serum VitB12 level & $-.396-$ & 0.000 \\
\hline hb * Serum VitB12 level & $-.370-$ & 0.000 \\
\hline
\end{tabular}

Table (5) Relation between Serum VitB12 level before and after phototherapy among cases group.

\begin{tabular}{lccccc}
\hline & & before phototherapy & after phototherapy & $\begin{array}{c}\text { Paired sample } \\
\text { t.test }\end{array}$ & Palue \\
\hline $\begin{array}{l}\text { Serum VitB12 } \\
\text { level }\end{array}$ & Mean \pm SD & $211.50 \pm 26.02$ & $324.1 \pm 7.5$ & $9.62-$ & 0.000 \\
\hline
\end{tabular}




\section{Discussion}

This examination indicated that, there were no measurably critical distinction among cases and controls as with respect to (sex, age, gestational age).

This concurred with [6] who found that, there were no between bunch contrasts in sex, gestational age.

This investigation indicated that, most cases were conveyed by CS (64\%).

This concurs with [7] who showed that among the hyperbilirubinemic children, (69\%) were conceived by cesarean segment.

This can't help contradicting the discoveries of another examination [8] who found that, there is no connection between the sort of conveyance and jaundice in infants.

This examination demonstrated that, quiet gathering was altogether connected with higher TSB when contrasted with control gathering.

This concurs with [9] who found that, the serum bilirubin level among youngsters of the examination bunch was $15.4 \pm 1.94 \mathrm{mg} / \mathrm{dl}$, while the serum bilirubin level among the children of the benchmark group was $6.6 \pm 0.79 \mathrm{mg} / \mathrm{dl}$. There was exceptionally measurable critical contrast between both considered gatherings with respect to add up to serum bilirubin level $(\mathrm{P}<0.001)$

This investigation demonstrated that, there were measurably huge decline in Serum VitB12 level among cases bunch than control gathering.

This concurs with [10] who found that the mean vitB12 level in patients was $119.9 \pm 43.9 \mathrm{ng} / \mathrm{L}(42.35$ - $178 \mathrm{ng} / \mathrm{L})$ while in controls was $286.17 \pm 97.43$ ng/L (207.90 - 624.10 ng/L).

This concurs likewise with [5] who found that, the nutrient B12 serum levels were altogether lower than in children with aberrant hyperbilirubinemia than controls $(\mathrm{P}$-esteem $=0.001)$.

Jaundice is the most widely recognized condition that requires clinical consideration and emergency clinic confirmation in babies. In many babies, unconjugated hyperbilirubinemia mirrors an ordinary temporary marvel. Be that as it may, in certain newborn children, serum bilirubin levels may rise unnecessarily, which can be a reason for concern on the grounds that unconjugated bilirubin is neurotoxic causing deep rooted neurologic sequelae in babies who endure [11].

VitB12 (Cobalamin) is a water-solvent nutrient that is gotten from creature items. Inherent factor (IF) is a glycoprotein that is created by the parietal cells in the stomach and it is fundamental for the ingestion of vitB12 in the terminal ileum. When consumed, vitB12 is utilized as a cofactor for proteins that are engaged with the amalgamation of DNA, unsaturated fats, and myelin. Subsequently, vitB12 insufficiency can prompt hematologic and neurologic indications [4].

This investigation demonstrated that, there were factually huge negative relationship between's serum
VitB12 level and (complete serum bilirubin levels (TSB) and DSB.

This concurs with [12] who found that, neonatal vitB12 adversely associated with neonatal TSB and DSB.

This investigation demonstrated that, serum VitB12 level was expanded after phototherapy.

No investigations evaluated connection between Serum VitB12 level when phototherapy.

S.Shahriarpanah [1] found that, the mean of serum nutrient $\mathrm{D}$ altogether expanded after phototherapy ( $\mathrm{P}<0.0001)$. Their examination indicated that phototherapy could build the degree of nutrient $\mathrm{D}$.

Hyperbilirubinemia or jaundice is a typical issue and it is regularly viewed as considerate in newborn children. Jaundice may be seen at the birth or any time during outset. In this manner, if hyperbilirubinemia, which is non-formation, isn't dealt with right on time, bilirubin crosses the bloodcerebrum boundary and applies its neurotoxic impacts. Its treatment incorporates medication treatment, blood change, and phototherapy [13]. Phototherapy is a restorative technique with the accompanying results: rashes, parchedness, increment in internal heat level, visual injury, hypocalcemia, hypomagnesemia, and so on [14]. One of the components impacted by phototherapy is nutrient. In spite of the fact that, nutrient and bilirubin have two unmistakable courses of digestion, yet, since some portion of their blends is basic in the liver, they may impact each other's union. Consequently, it very well may be inferred that phototherapy may impact the degree of blood in the two components [15].

In the investigation by [16], plasma level of nutrient D expanded 48 hours after phototherapy, and the expansion was huge.

\section{Conclusion}

Full term neonates with indirect hyperbilirubinemia had lower serum levels of vitamin B12 than healthy full term neonates. Phototherapy could increase the level of serum vitamin B12 in neonates with indirect hyperbilirubinemia.

\section{References}

[1] S.Shahriarpanah, F. Haji Ebrahim Tehrani, A. Davati, Effect of Phototherapy on Serum Level of Calcium, Magnesium and Vitamin D in Infants with Hyperbilirubinemia. Iranian journal of pathology, Vol.13(3), PP.357-362,2018.

[2] S.Al-Banna, A.Riad, and S.Anis, The effect of Fenofibrate and Antioxidant Vitamins [D, E and C] in Treatment of Uncomplicated Neonatal Hyperbilirubinemia. Annals of Neonatology Journal,Vol. 2(1),PP. 37-48,2020.

[3] H.Boskabadi and M.Navaei, Relationship between delivery type and jaundice severity among newborns referred to Ghaem Hospital 
within a 6-year period in Mashhad. J Obstetr Gynecol,Vol.14(4),PP. 15 -21,2011.

[4] A.Ankar and S.S.Bhimji, Vitamin, B12 (Cobalamin), Deficiency. StatPearls. Treasure Island (FL): StatPearls Publishing, Vol.1,PP.2228,2017 .

[5] G.Mohamed, R.Abdel-Salam, and R.Mortada, Assessment of serum levels of vitamin B12 in full term neonates with indirect hyperbilirubinemia. Annals of Neonatology Journal,Vol. 2(1),PP. 2026,2020.

[6] H.C.Chou, C.T.Chien, P.N.Tsao, Prediction of severe neonatal hyperbilirubinemia using cord blood hydrogen peroxide: a prospective study. PLoS One,Vol.9(1),PP.718-720,2014.

[7] H.Boskabadi, F.Ashrafzadeh, F.Azarkish, Complications of Neonatal Jaundice and the Predisposing Factors in Newborns. J Babol Univ Med Sci,Vol.17,PP.7-13,2015.

[8] H.Boskabadi and M.Navaei, Relationship between delivery type and jaundice severity among newborns referred to Ghaem Hospital within a 6-year period in Mashhad. J Obstetr Gynecol,Vol.14(4) ,PP.15 -21,2011.

[9] M.H.Bahbah, F.M.ElNemr, R.S.ElZayat, Effect of phototherapy on serum calcium level in neonatal jaundice. Menoufia Med J,Vol.28,PP.426-30 ,2015.
[10] N.Eroglu, Y.Kandur, S.Kalay, Neonatal hyperbilirubinemia in a Turkish cohort: Association of vitamin B12. J Clin Med Res,Vol.7,PP.556-559,2015.

[11] S.Mitra and J.Rennie Neonatal jaundice: aetiology, diagnosis and treatment. $\mathrm{Br} \mathbf{J}$ Hosp Med (Lond) ,Vol.78,PP.699-704,2017.

[12] R.A.A.Aziz and M.A.A.Elela, Correlation Between Maternal and Neonatal Vitamin B12 Serum Levels in Fullterm Neonates with Physiologic Jaundice. Int J Pediatr Neonat Care ,Vol.4,PP.137-139,2018.

[13] R.Martin, A.Fanaroff and M.Walsh, Disorders of Calcium, Phosphorus, and Magnesium in the Neonate. Neonatal-Perinatal Medicine. Elsevier,Vol.22,PP.1461-1489,2015.

[14] N.Khosravi, A.Aminian and R.Taghipour, Total se- rum magnesium level in icteric neonates before and after phototherapy. Tehran Univ Med J,Vol.69,PP.432-437,2011.

[15] M.Mutlu, A.Cayir, Y.Cayir, Vitamin D and Hyperbilirubinemia in Neo- nates. HK J Pediatr,Vol.18,PP.77-81,2013.

[16] M.Barak, M.Mirzarahimi, M.Eghbali, The Effect of Phototherapy Duration on Serum Level of Total Calcium and 25-hydroxy vita- min D $(25(\mathrm{OH}) \mathrm{D})$ in Jaundiced Neonates. Int $\mathrm{J}$ Health Rehabil Sci,Vol.123(127),PP.3-4,2014. 